\author{
Artur K. Modrzejewski ${ }^{*}$
}

\title{
ŚRODOWISKO DOBREM CHRONIONYM PRZEZ „ZAINTERESOWANĄ SPOŁECZNOŚĆ" W GOSPODAROWANIU ODPADAMI WYDOBYWCZYMI
}

\section{Wstęp}

Oceniając polską Konstytucję w zakresie dotyczącym ochrony środowiska stwierdzić można, że dominuje w niej przedmiotowe ujęcie środowiska jak swego rodzaju dobra wspólnego, na którego straży w interesie publicznym stać ma władza ${ }^{1}$. Ochronę środowiska uznać należy za interes publiczny. Środowisko ma wielką wartość, która powinna być chroniona, jako dobro wspólne. Za ochroną tego dobra przemawia interes publiczny, czasami w literaturze określany interesem społecznym ${ }^{2}$. Zgodnie z art. 74 ust. 2 Konstytucji ochrona środowiska jest obowiązkiem władz publicznych. $Z$ kolei na podstawie art. 74 ust. 4 władze publiczne wspierają działania obywateli na rzecz ochrony i poprawy stanu środowiska ${ }^{3}$. Unormowania konstytucyjne jednoznacznie nakładają na organy administracji publicznej obowiązek podejmowania działań w celu ochrony środowiska przy jednoczesny zaangażowaniu czynnika społecznego.

Ostatnimi czasy dokonano szeregu zmian w regulacjach prawych odnoszących się do postępowania z odpadami. 13 stycznia 2013 r. weszła w życie ustawa z dnia 16 listopada 2012 r. o zmianie ustawy o odpadach wydobywczych oraz niektórych innych ustaw ${ }^{4}$. Wprowadzona zmiana ma na celu pełne wdrożenie przez Polskę przepisów dyrektywy Parlamentu Europejskiego i Rady 2006/21/ WE z dnia 15 marca 2006 r. w sprawie gospodarowania odpadami pochodzącymi

\footnotetext{
* Dr, Zakład Prawa Ochrony Środowiska i Nauki Administracji Publicznej, Wydział Prawa Uniwersytetu w Białymstoku.

${ }^{1}$ B. Rakoczy, Ograniczenie prawa wolności jednostki ze względu na ochronę środowiska w Konstytucji Rzeczypospolitej Polskiej, Toruń 2006, s. 7.

2 J. Ciechanowicz-McLean, Prawo i polityka ochrony środowiska, Warszawa 2009, s. 58.

${ }_{3}^{3}$ Konstytucja Rzeczypospolitej Polskiej z dnia 2 kwietnia 1997 r., Dz. U. nr, 78, poz. 483.

${ }^{4}$ Ustawa z dnia 16 listopada 2012 r. o zmianie ustawy o odpadach wydobywczych oraz niektórych innych ustaw, Dz. U. poz. 1513.
} 
z przemysłu wydobywczego oraz zmieniającej dyrektywę 2004/35/WE ${ }^{5}$. Ponieważ postanowienia dyrektywy 2006/21/WE zostały implementowane do krajowego porządku prawnego w sposób niepełny, Komisja Europejska wszczęła przeciwko Polsce postępowanie $\mathrm{w}$ sprawie naruszenia prawa wspólnotowego (naruszenie nr 2011/2001). Celem zamiany ustawy jest również transpozycja kilku innych decyzji Komisji Europejskiej uzupełniających postanowienia zawarte w dyrektywie 2006/21/WE, takich jak:

1) decyzja Komisji 2009/337/WE z dnia 20 kwietnia 2009 r. w sprawie definicji kryteriów klasyfikacji obiektów unieszkodliwiania odpadów zgodnie z załącznikiem III do dyrektywy 2006/21/WE Parlamentu Europejskiego i Rady w sprawie gospodarowania odpadami pochodzącymi z przemysłu wydobywczego (Dz. Urz. UE L 102 z 22.04.2009, s. 7);

2) decyzja Komisji 2009/360/WE z dnia 30 kwietnia 2009 r. uzupełniająca wymogi techniczne w odniesieniu do charakterystyki odpadów ustanowionej dyrektywą 2006/21/WE Parlamentu Europejskiego i Rady w sprawie gospodarowania odpadami pochodzącymi z przemysłu wydobywczego (Dz. Urz. UE L 110 z 01.05.2009, s. 48);

3) decyzja Komisji 2009/359/WE z dnia 30 kwietnia 2009 r. uzupełniająca definicję odpadów obojętnych w związku z wykonaniem przepisów art. 22 ust. 1 lit. f dyrektywy 2006/21/WE Parlamentu Europejskiego i Rady w sprawie gospodarowania odpadami - 2 - pochodzącymi z przemysłu (Dz. Urz. UE L 110 z 01.05.2009, s. 46);

4) decyzja Komisji 2009/358/WE z dnia 29 kwietnia 2009 r. w sprawie harmonizacji, regularnego przekazywania informacji oraz kwestionariusza, o których mowa w art. 22 ust. 1 lit. a oraz art. 18 dyrektywy 2006/21/WE Parlamentu Europejskiego i Rady w sprawie gospodarowania odpadami pochodzącymi z przemysłu wydobywczego.

Oprócz wielu nowych regulacji i obowiązków np. ustawa nakłada na posiadacza odpadów obowiązek ich odzysku lub unieszkodliwienia wyłącznie w obiekcie przystosowanym do składowania określonego rodzaju odpadów, ustawodawca wskazał, że jednym z celów programu gospodarowania odpadami wydobywczymi jest racjonalne gospodarowanie odpadami wydobywczymi, które musi być realizowane już w momencie projektowania działalności wydobywczej, a nie jak wynika z przepisów dotychczas obowiązujących, w fazie działalności wydobywczej i przy wyborze metody wydobywania kopalin ze złóż oraz ich przeróbki ${ }^{6}$. Racjonalność służyć ma realizacji celów dyrektywy 2006/21/WE.

${ }^{5}{ }^{5}$ Dyrektywa Parlamentu Europejskiego i Rady 2006/21/WE z dnia 15 marca 2006 r. w sprawie gospodarowania odpadami pochodzącymi z przemysłu wydobywczego oraz zmieniającej dyrektywę 2004/35/WE, Dz. Urz. UE L 102 z 11.04.2006, s. 15.

${ }^{6}$ Ł. Matlacz, Nowe zasady gospodarowania odpadami pochodzacymi z przemystu wydobywczego, http://www.srodowisko.abc.com.pl/czytaj/-/artykul/nowe-zasady-gospodarowania-odpadami-pochodzacymi-z-przemyslu-wydobywczego (odczyt 03.10.2013). 
W art. 3 ust. 1 ustawy o odpadach wydobywczych zaproponowano zmiany mające na celu dostosowanie brzmienia definicji „obiektu unieszkodliwiania odpadów wydobywczych”, „poważnego wypadku”, „rekultywacji terenu” oraz „zainteresowanej społeczności” do brzmienia definicji zawartych w dyrektywie 2006/21/WE. Wprowadzenie pojęcia „zainteresowanej społeczności” wiąże się z przyznaniem jej również instrumentów prawnych służących ochroni środowiska. W referacie chciałbym wskazać, jak należy rozumieć interpretować pojęcie „zainteresowanej społeczności” oraz, jakie działania podejmować może zainteresowana społeczność na rzecz ochrony środowiska na gruncie ustawy o odpadach wydobywczych.

\section{Kim jest zainteresowana społeczność?}

Zgodnie z nową definicją, zamieszczoną w art. 3 ust. 1 pkt 14 ustawy o odpadach wydobywczych, zainteresowana społeczność są to osoby fizyczne, osoby prawne lub jednostki organizacyjne nieposiadające osobowości prawnej, które są lub mogą być dotknięte skutkami wydania zezwolenia lub mają interes w procesie jego wydania lub $\mathrm{w}$ procesie ustalania procedur związanych z zapobieganiem poważnym wypadkom w obiektach unieszkodliwiania odpadów wydobywczych kategorii A, a także organizacja ekologiczna, o której mowa w art. 3 ust. 1 pkt 10 ustawy z dnia 3 października 2008 r. o udostępnianiu informacji o środowisku $\mathrm{i}$ jego ochronie, udziale społeczeństwa $\mathrm{w}$ ochronie środowiska oraz o ocenach oddziaływania na środowisko?.

Definicja ta nie jest do końca zgodna $\mathrm{z}$ definicją zamieszczoną $\mathrm{w}$ dyrektywie 2006/21/WE. Zgodnie z nią zainteresowana społeczność oznacza część społeczeństwa, która jest lub może być dotknięta skutkami lub ma interes w procesie podejmowania decyzji w sprawie środowiska, zgodnie z art. 6 i 7 niniejszej dyrektywy; do celów niniejszej definicji, organizacje pozarządowe działające na rzecz ochrony środowiska i spełniające wszelkie wymogi zgodnie z prawem krajowym uważa się za mające taki interes.

Dokonując wykładni językowej definicji zawarte w dyrektywie należy zwrócić uwagę na to, że po pierwsze zainteresowaną społecznością będzie część społeczeństwa, czyli raczej grupa osób. Dyrektywa nie zawiera sformułowań „każdy”, ,jednostka" itp. Jest to więc pewna zbiorowość. Grupa osób może być aktualnie dotknięta skutkami działań, lub też wpływ tych skutków może nastąpić w przyszłości. Dopiero w dalszej części definicji udział zainteresowanej społeczności $\mathrm{w}$ postępowaniu związany jest $\mathrm{z}$ interesem prawnym $\mathrm{w}$ procesie podejmowania

${ }^{7}$ Ustawa z dnia 3 października 2008 r. o udostępnianiu informacji o środowisku i jego ochronie, udziale społeczeństwa w ochronie środowiska oraz o ocenach oddziaływania na środowisko, Dz. U. nr 199, poz. 1227, z późn. zm. 
decyzji. Uznać należy, że w zasadzie każda organizacja społeczna (pozarządowa) bez względu na posiadanie interesu prawnego uznana będzie z mocy prawa za przedstawiciela zainteresowanej społeczności w postępowaniu prowadzonym na gruncie dyrektywy. Tak sformułowana definicja obejmuje swym zakresem bardzo szeroki katalog podmiotów zarówno o sformalizowanym, jak i niesformalizowanym charakterze. Definicja wprowadzona w polskiej ustawie o odpadach wydobywczych (art. 3 ust. 1 pkt 14) nie jest tożsama z definicją zawartą w dyrektywie. Rozumienie tego, kogo uznajemy za zainteresowaną społeczność w polskim porządku prawym związane jest $\mathrm{z}$ wewnątrzkrajowymi uregulowaniami ${ }^{8}$.

Brak tożsamości podanych definicji podnoszony był na etapie nowelizowania ustawy o odpadach wydobywczych. Podkreślano, że w polskim systemie prawnym nie jest jednoznacznie określone, jakoby „zainteresowaną społecznością” były z mocy prawa wszelkie organizacje pozarządowe, które działają na rzecz ochrony środowiska, o ile jednocześnie spełniają przesłanki do uznania ich za takie organizacje zgodnie z prawem krajowym ${ }^{9}$. W definicji pojęcia ,zainteresowana społeczność" usunięto odesłanie do art. 31 kodeksu postępowania administracyjnego (dalej k.p.a.) w odniesieniu do organizacji pozarządowych ${ }^{10}$.

Procedura administracyjna stawia organizację społeczną w roli podmiotu o szerokim spektrum możliwości udziału. Może ona bowiem występować zarówno, jako strona postępowania, gdy posiada w dennej sprawie interes prawny, bądź też jako podmiot tylko zajmujący stanowisko w danej sprawie. Bez wątpienia organizacja może uczestniczyć w procedurze, jako podmiot na prawach strony, bądź też nieuczestnicząca ma możliwość przedstawienia organowi swojego poglądu w danej sprawie, wyrażonego w uchwale bądź oświadczeniu jej organu statutowego ${ }^{11}$.

Zgodnie z art. 31 k.p.a. organizacja społeczna może w sprawie dotyczącej innej osoby występować z żądaniem: wszczęcia postępowania, dopuszczenia jej do udziału w postępowaniu, jeżeli jest to uzasadnione celami statutowymi tej organizacji i gdy przemawia za tym interes społeczny. Organ administracji publicznej, uznając żądanie organizacji społecznej za uzasadnione, postanawia o wszczęciu postępowania z urzędu lub o dopuszczeniu organizacji do udziału w postępowaniu. Na postanowienie o odmowie wszczęcia postępowania lub dopuszczenia do udziału w postępowaniu organizacji społecznej służy zażalenie. Organizacja społeczna uczestniczy w postępowaniu na prawach strony. Organ administracji publicznej, wszczynając postępowanie w sprawie dotyczącej innej

${ }^{8}$ Ustawa z dnia 10 lipca 2008 r. o odpadach wydobywczych, tekst jedn. Dz. U.2013.1136.

9 M. Szydło, Opinia prawna na temat projektu ustawy o zmianie ustawy o odpadach wydobywczych oraz niektórych innych ustaw, „Zeszyty Prawnicze” 2012, nr 4, s. 201.

${ }^{10}$ Ustawa z dnia 14 czerwca 1960 r. Kodeks postępowania administracyjnego, tekst jedn. Dz. U. z 2013, poz. 267.

${ }^{11}$ D.J. Kościuk, Udział organizacji spolecznych w samorzadowych infrastrukturalnych procesach inwestycyjnych, „Samorząd Terytorialny” 2010, nr 1-2, s. 74. 
osoby, zawiadamia o tym organizację społeczną, jeżeli uzna, że może ona być zainteresowana udziałem $\mathrm{w}$ tym postępowaniu ze względu na swoje cele statutowe, i gdy przemawia za tym interes społeczny. Organizacja społeczna, która nie uczestniczy w postępowaniu na prawach strony, może za zgodą organu administracji publicznej przedstawić temu organowi swój pogląd w sprawie, wyrażony w uchwale lub oświadczeniu jej organu statutowego ${ }^{12}$.

Argumentem za usunięciem odesłania do k.p.a. było to, że kodeks, określając krąg stron postępowania, nie dopuszcza wszystkich organizacji pozarządowych, jako posiadających interes do uczestniczenia w takim postępowaniu. Nie gwarantowało to zatem udziału organizacji pozarządowych w postępowaniu administracyjnym, co stało w sprzeczności z dyrektywą 2006/21/WE. Odesłanie do k.p.a oznaczało m.in. że organizacja pozarządowa, w tym organizacja zajmująca się sprawami ochrony środowiska, może w sprawie dotyczącej innego podmiotu występować z żądaniem wszczęcia postępowania lub dopuszczenia jej do udziału w postępowaniu, np. w postępowaniu w sprawie wydania zezwolenia na prowadzenie obiektu unieszkodliwiania odpadów, jeżeli jest to uzasadnione celami statutowymi tej organizacji lub gdy przemawia za tym interes społeczny. O tym, czy organizacja społeczna zostanie dopuszczona do postępowania decyduje jednak każdorazowo organ administracji.

Definicja „zainteresowanej społeczności” odsyła do ustawy z dnia 3 października 2008 r. o udostępnianiu informacji o środowisku i jego ochronie, udziale społeczeństwa $\mathrm{w}$ ochronie środowiska oraz o ocenach oddziaływania na środowisko $^{13}$. Zgodnie z tą ustawą, organizacja ekologiczna to organizacja społeczna, która w statutowych celach działalności ma wpisaną ochronę środowiska (której statutowym celem jest ochrona środowiska). W prawie ochrony środowiska istotny jest udział czynnika społecznego. Partycypacją społeczną jest proces, w którym przedstawiciele społeczeństwa wpływają na decyzje organów administracji publicznej, co ma bezpośredni lub pośredni wpływ na ich sytuację prawną. Partycypacja ma prowadzić do tego, by zainteresowane problemem instytucje w sposób czynny włączały się w procesy decyzyjne ${ }^{14}$.

Status prawny organizacji ekologicznej włączającej się do postępowania na podstawie ustawy o dostępie do informacji o środowisku w sposób znaczny rożni się od pozycji tej organizacji podejmującej działania na podstawie k.p.a. Przede wszystkim, by organizacja ekologiczna, która zgłosiła chęć uczestniczenia w sprawie, mogła rozpoczać działanie nie musi czekać, jak to ma miejsce w „zwykłym" postępowaniu administracyjnym, na postanowienie organu o dopuszczeniu

12 Ustawa z dnia 14 czerwca 1960 r. Kodeks postepowania administracyjnego.

${ }^{13}$ Ustawa z dnia 3 października 2008 r. o udostępnianiu informacji o środowisku i jego ochronie, udziale społeczeństwa w ochronie środowiska oraz o ocenach oddziaływania na środowisko.

${ }_{14}$ W. Dworak, A. Haładyj, A. Kozińska, Partycypacja społeczna w ochronie środowiska, [w:] M. Domagała, A. Haładyj, S. Wrzosek (red.), Encyklopedia prawa administracyjnego, Warszawa 2013, s. 267. 
do udziału w postępowaniu. W postępowaniu z udziałem społeczeństwa wystarczy jednostronne oświadczenie organizacji o chęci uczestniczenia w postępowaniu, nie ma podstaw prawnych do tego, aby organ wydawał w tej sprawie ,pozytywne" postanowienie. Podkreśla się to również w orzecznictwie, co prawda w stanie faktycznym i prawnym przed nowelizacją prawa ochrony środowiska ale zachowującym aktualność (w poprzednim stanie prawy tryb dopuszczenia organizacji ekologicznej do postepowania określała ustawa prawo ochrony środowiska) ${ }^{15}$. $\mathrm{O}$ ile na podstawie k.p.a. w postępowaniu może uczestniczyć każda organizacja ekologiczna, bo wynika to z jej celów statutowych i przemawia za tym interes społeczny (art. $31 \S 1$ k.p.a.), o tyle na podstawie art. 33 ust. 1 p.o.ś. może uczestniczyć tylko taka organizacja ekologiczna, której uczestnictwo wynika z miejsca jej działania. Warunkiem formalnym uczestnictwa na zasadach k.p.a. jest żądanie organizacji i postanowienie o dopuszczeniu do udziału na prawach strony, natomiast uczestnictwo na prawach strony na podstawie art. 33 ust. 1 p.o.ś. wymaga chęci złożenia uwag i wniosków ${ }^{16}$. Dopuszczenie organizacji ekologicznej do udziału w postępowaniu na gruncie ustawy od udostępnianiu informacji o środowisku i jego ochronie, udziale społeczeństwa w ochronie środowiska oraz ocenach oddziaływania na środowisko nie wymaga wydania postanowienia. Organ prowadzący postępowanie wydaje postanowienie jedynie w przypadku odmowy dopuszczenia organizacji do udziału w sprawie. Skoro wyłączenia pewnej kategorii podmiotów od udziału w postępowaniu administracyjnym nie można domniemywać, gdyż może to mieć miejsce tylko wówczas, gdy przepis prawa wyraźnie tak stanowi, należy przyjąć, że w tych kategoriach spraw, w których ustawodawca przewidział możliwość udziału społeczeństwa, będzie mogła uczestniczyć tylko ta grupa organizacji społecznych, które będą mogły być uznane za organizacje ekologiczne. Natomiast w pozostałych kategoriach spraw będą mogły uczestniczyć na ogólnych zasadach, po spełnieniu wymagań wynikających z art. $31 \S 1$ k.p.a, wszystkie organizacje społeczne ${ }^{17}$.

W „zwykłym” postepowaniu kładzie się nacisk na należyte wykazanie realizacji przez organizacje społeczną celu społecznego. Udział organizacji społecznej w postępowaniu administracyjnym na prawach strony nie może służyć partykularnym celom samej organizacji społecznej, lecz musi odpowiadać wymaganiom racjonalnie pojmowanej kontroli społecznej nad postępowaniem administracyjnym w sprawach indywidualnych i działaniem w nim organów administracyjnych. $\mathrm{Z}$ przepisu art. 31 § 1 in fine k.p.a. wynika, że żądanie organizacji społecznej dopuszczenia do udziału w postępowaniu musi być uzasadnione celami statutowymi tej organizacji. Musi zatem istnieć merytoryczne powiązanie przedmiotu postę-

15 Art. 31 uchylony przez art. 144 pkt 9 ustawy z dnia 3 października 2008 r. o udostępnianiu informacji o środowisku i jego ochronie, udziale społeczeństwa w ochronie środowiska oraz o ocenach oddziaływania na środowisko (Dz. U. 2008.199.1227) z dniem 15 listopada $2008 \mathrm{r}$.

16 Wyrok NSA z 7 kwietnia 2011, sygn. II OSK 2546/10, LEX nr 992528.

17 Wyrok WSA we Wrocławiu z 27 maja, sygn. II SA/Wr 89/10, LEX nr 674622. 
powania administracyjnego z celami i zakresem działania organizacji społecznej. Organ powinien zatem ocenić, czy między celami statutowymi organizacji społecznej a przedmiotem sprawy administracyjnej rozstrzyganej w drodze decyzji administracyjnej istnieje powiązanie merytoryczne w sensie prawnym, a nie tylko faktycznym. Nawet wtedy jednak, gdy udział organizacji społecznej w postępowaniu jest uzasadniony jej celami statutowymi, organ administracji publicznej może uznać żądanie organizacji społecznej za niezasadne ze względu na interes społeczny. Organizacja społeczna ubiegająca się o dopuszczenie jej do udziału w postępowaniu winna uprawdopodobnić, że przyczyni się do lepszego wypełnienia przez postępowanie administracyjne jego celów. Natomiast na organie administracji spoczywa cały ciężar zweryfikowania zasadności bądź niezasadności dopuszczenia organizacji społecznej ${ }^{18}$. W przypadku organizacji ekologicznej istotne jest by celem realizowanym przez organizację była ochrona środowiska. W tym kontekście organizacja ekologiczna spełniała będzie cechy zainteresowanej społeczności, która gdy pojawia się zagrożenie środowiska powinna aktywnie uczestniczyć w toczącym się postępowaniu.

\section{Działania zainteresowanej społeczności na rzecz ochrony środowiska}

W dyrektywie 2006/21/WE przewidziano bezpośredni udział zainteresowanej społeczności w kilku etapach i fazach postępowania. W ten sposób zaangażowanie społeczeństwa ma służyć ochronie dobra, jakim jest środowisko naturalne. Dyrektywa zawiera wskazanie, że państwa członkowskie powinny mieć obowiązek zapewnienia, że zgodnie z konwencją ONZ/EKG o dostępie do informacji, udziale społeczeństwa w podejmowaniu decyzji oraz dostępie do sprawiedliwości w sprawach dotyczących środowiska z dnia 25 czerwca 1998 r. (konwencja z Aarhus) społeczeństwo jest informowane o złożeniu wniosku o zezwolenie na gospodarowanie odpadami, a zainteresowana społeczność jest konsultowana przed udzieleniem zezwolenia na gospodarowanie odpadami.

Państwa członkowskie zapewniają, aby zainteresowana społeczność miała zapewnioną z wyprzedzeniem skuteczną możliwość uczestnictwa w opracowywaniu lub przeglądzie zewnętrznego planu awaryjnego ${ }^{19}$. W tym celu zainteresowana

18 Wyrok NSA z 11 kwietnia 2012 r., sygn. akt II OSK 122/11, Centralna Baza Orzeczeń Sądowych (www.orzeczenia.nsa.gov.pl).

19 „Zewnętrzny plan awaryjny” - właściwy organ sporządza zewnętrzny plan awaryjny wyszczególniający środki, które należy podjąć poza miejscem prowadzenia działalności w razie wypadku (dyrektywa Parlamentu Europejskiego i Rady 2006/21/WE z dnia 15 marca 2006 r. w sprawie gospodarowania odpadami pochodzącymi z przemysłu wydobywczego oraz zmieniającej dyrektywę 2004/35/WE) 
społeczność jest informowana o wszelkich takich propozycjach oraz udostępniane są jej odpowiednie informacje, w tym, między innymi, informacje o prawie uczestnictwa w procesie decyzyjnym oraz o właściwym organie, do którego mogą być zgłaszane uwagi i pytania. Państwa członkowskie zapewniają, aby zainteresowana społeczność miała prawo w uzasadnionych ramach czasowych do wyrażania uwag, oraz aby przy podejmowaniu decyzji w sprawie zewnętrznego planu awaryjnego uwagi te były w należyty sposób brane pod uwagę. Państwa członkowskie zapewniają, aby informacje w sprawie środków bezpieczeństwa oraz w sprawie działań wymaganych $w$ razie wypadku, zawierające przynajmniej elementy wymienione w sekcji 2 załącznika ${ }^{20}$, były przekazywane zainteresowanej społeczności bezpłatnie i bez dodatkowych warunków.

Informacje takie podlegają przeglądowi co trzy lata i, jeżeli jest to konieczne, są uaktualniane. Państwa członkowskie zapewniają, aby w odpowiednich ramach czasowych, zainteresowanej społeczności były udostępniane:

a) zgodnie z prawem krajowym, główne sprawozdania i opinie przekazane właściwemu organowi w czasie;

b) zgodnie z przepisami dyrektywy 2003/4/WE Parlamentu Europejskiego i Rady z dnia 28 stycznia 2003 r. w sprawie publicznego dostępu do informacji dotyczących środowiska wszelkie informacje, które mają znaczenie dla decyzji i które stają się dostępne dopiero po poinformowaniu społeczeństwa.

Zainteresowana społeczność ma prawo do wyrażania uwag i opinii właściwym organom przed podjęciem decyzji. Wyniki konsultacji przeprowadzonych zgodnie z niniejszym artykułem są należycie brane pod uwagę przy podejmowaniu decyzji. Kiedy decyzja zostaje podjęta, właściwy organ, zgodnie z odpowiednimi procedurami, informuje zainteresowaną społeczność i udostępnia jej następujące informacje:

a) treść decyzji, w tym kopię zezwolenia;

b) przesłanki i powody, na których oparto decyzję.

Przewiduje się również udział zainteresowanej społeczności pojawienia się relacji transgranicznych związanych z odpadami wydobywczymi. Załącznik nr 1 zawiera szczegółowe wytyczne dotyczące polityki zapobiegania poważnym wypadkom i informacje, które mają być przekazane zainteresowanej społeczności.

Zgodnie z polską ustawą o odpadach wydobywczych, właściwy komendant wojewódzki Państwowej Straży Pożarnej zapewnia możliwość udziału zainteresowanej społeczności w postępowaniu, którego przedmiotem jest sporządzenie zewnętrznego planu operacyjno-ratowniczego, na zasadach i w trybie określonych w ustawie z dnia 3 października 2008 r. o udostępnianiu informacji o środowisku i jego ochronie, udziale społeczeństwa w ochronie środowiska oraz o ocenach od-

20 Załącznik ten zawiera Informacje, które mają być przekazywane zainteresowanej społeczności (dyrektywa Parlamentu Europejskiego i Rady 2006/21/WE z dnia 15 marca 2006 r. w sprawie gospodarowania odpadami pochodzącymi z przemysłu wydobywczego oraz zmieniającej dyrektywę 2004/35/WE). 
działywania na środowisko. Właściwy komendant wojewódzki Państwowej Straży Pożarnej sporządza informację o środkach bezpieczeństwa oraz o działaniach podejmowanych $\mathrm{w}$ razie wystąpienia poważnego wypadku. Zakres informacji jest określony w załączniku nr 2 do ustawy. Informacje opracowywane przez właściwego komendanta wojewódzkiego Państwowej Straży Pożarnej, które mają być przekazane zainteresowanej społeczności, obejmują:

1) imię i nazwisko oraz adres zamieszkania lub nazwę i adres siedziby posiadacza odpadów prowadzącego obiekt unieszkodliwiania odpadów wydobywczych oraz adres obiektu unieszkodliwiania odpadów wydobywczych;

2) oznaczenie osoby dostarczającej informacje, według zajmowanego stanowiska;

3) znak i datę wydania pozwolenia na wytwarzanie odpadów, pozwolenia zintegrowanego lub zezwolenia na prowadzenie obiektu unieszkodliwiania odpadów wydobywczych;

4) proste i jasne objaśnienie działań podejmowanych w miejscu prowadzenia działalności;

5) przedstawioną językiem niespecjalistycznym ogólną klasyfikację niebezpieczeństwa substancji i preparatów występujących w obiekcie unieszkodliwiania odpadów wydobywczych, jak również odpadów wydobywczych, które mogłyby spowodować poważny wypadek, ze wskazaniem ich głównych niebezpiecznych właściwości;

6) ogólne informacje dotyczące charakteru ryzyka wystąpienia poważnych wypadków, z uwzględnieniem ich potencjalnych skutków dla zainteresowanej społeczności i środowiska;

7) informacje dotyczące ostrzegania zainteresowanej społeczności oraz informowania jej w razie poważnego wypadku;

8) informacje dotyczące działań, które zainteresowana społeczność powinna podjąć, oraz sposobu, w jaki należy się zachować w razie poważnego wypadku;

9) potwierdzenie konieczności dokonania odpowiednich ustaleń przez posiadacza odpadów prowadzącego obiekt unieszkodliwiania odpadów wydobywczych w miejscu prowadzenia działalności, a szczególnie współpracy ze służbami ratowniczymi w celu reagowania na poważne wypadki oraz zmniejszenia ich skutków;

10) odniesienia do zewnętrznych planów operacyjno-ratowniczych, sporządzonych w celu reagowania na wszelkie skutki poważnego wypadku poza miejscem prowadzenia działalności; odniesienia te powinny zawierać wskazanie, by stosować się do wszelkich instrukcji lub wymagań służb ratowniczych podczas wypadku;

11) szczegóły dotyczące tego, gdzie można uzyskać dodatkowe informacje, z zastrzeżeniem wymogów dotyczących zachowania poufności informacji ustanowionych w przepisach odrębnych ${ }^{21}$.

Informacja ta jest przekazywana zainteresowanej społeczności bezpłatnie

${ }^{21}$ Ustawa z dnia 10 lipca 2008 r. o odpadach wydobywczych. 
i niezwłocznie w sposób zwyczajowo przyjęty oraz publikowana w „Biuletynie Informacji Publicznej”, na stronie podmiotowej organu. Właściwy komendant wojewódzki Państwowej Straży Pożarnej jest obowiązany do analizy zewnętrznego planu operacyjno-ratowniczego oraz informacji, co najmniej raz na 3 lata, w celu ich aktualizacji, z uwzględnieniem w szczególności zmian wprowadzonych $\mathrm{w}$ procesie technologicznym obiektu unieszkodliwiania odpadów wydobywczych kategorii. Informowanie zainteresowanej społeczności uznać można za instrument ochronny dobra publicznego jakim jest środowisko.

\section{Zakończenie}

Zmiana ustawy o odpadach wydobywczych wprowadziła do polskiego porządku prawnego definicję zainteresowanej społeczności. Porównując instrumenty prawne, jakie przyznane zostały zainteresowanej społeczności na gruncie dyrektywy Parlamentu Europejskiego i Rady 2006/21/WE z dnia 15 marca 2006 r. w sprawie gospodarowania odpadami pochodzącymi z przemysłu wydobywczego oraz zmieniającej dyrektywę 2004/35/WE oraz zmienionej ustawy o odpadach wydobywczych dochodzimy do wniosku, że w polskim systemie prawnym zainteresowana społeczność utożsamiana jest głównie z zorganizowanymi organizacjami ekologicznymi, mającymi uprawnienie do włączania się do postępowań w sprawie wydawania zezwoleń oraz z koniecznością konsultowania planów. Zakres podmiotowy definicji zainteresowanej społeczności na gruncie dyrektyw jest bardzo szeroki. W dyrektywie w sposób bezpośredni wskazuje się, w jaki sposób zainteresowana społeczność włączona powinna być w postępowanie dotyczące postępowania z odpadami wydobywczymi. Bez względu jednak na sposób regulacji, wynikający w dużej mierze ze specyfiki polskich rozwiązań prawnych, stwierdzić należy, że zainteresowana społeczność powinna być angażowana dla ochrony dobra wspólnego, jakim jest środowisko naturalne. 